\title{
INNER LIFE, MEANINGFUL WORK, CONDITIONS FOR COMMUNITY, AND ORGANISATIONAL CITIZENSHIP BEHAVIOUR
}

\author{
Rasheed Olawale AZEEZ ${ }^{1}$, Kabiru Ishola GENTY² \\ ${ }^{1,2}$ Lagos State University, Ojo, Lagos, Nigeria \\ Corresponding author's e-mail: r.azeez2002@gmail.com
}

\begin{abstract}
This paper investigated the relationship that exists among inner life, meaningful work, conditions for community, and organisational citizenship behaviour amongst Nigerian academics. The study embraced a quantitative approach using survey research design, which is ex post facto in nature with the engagement of quantitative and correlational methods. Thus, a convenience sampling technique was utilised to administer 328 questionnaires amongst the academics of two Nigerian public universities. Three hypotheses were stated and tested using inferential statistics tools via the IBM Statistical Package for the Social Sciences (SPSS) version 20 and the Analysis of Moment Structure (AMOS) version 22. The multivariate statistical processes used in this paper are confirmatory factor analyses, structural equation modelling, as well as model fit indices. The results indicated an insignificant positive relationship between inner life and organisational citizenship behaviour. However, it was evident that a strong positive relationship existed between conditions for community and organisational citizenship behaviour. In contrast, the study revealed that there was no significant relationship between meaningful work and organisational citizenship behaviour. Therefore, this paper concludes that the management of universities should always communicate the mutual benefit of engaging in organisational citizenship behaviour to the members of their staff through effective conditions for community, such as aiding of staff personal growth and fair evaluation of work.
\end{abstract}

Keywords: Conditions for community, inner life, meaningful work, organizational citizenship behavior.

JEL Classification: M12, M54.

\section{INTRODUCTION}

The bedrock of an organisation is its staff. It is necessary to have the right people in the right number and value and who are committed to serving the organisation (Starineca, 2016; Suleiman, Ismail, Nor \& Long, 2012). In a typical Nigerian work environment, especially an academic environment where novelty and development of rare, unique and exceptional human resource take place, agents of transformation (academics) must take up extra duties, be obedient to rulebooks, maintain and develop a helpful attitude and tolerance of work dissatisfaction (Ahmadi, Nami \& Barvarz, 2014). This becomes necessary so as to achieve their specified aims. Thus, when all these are done by people in the organisation, they 
are said to be demonstrating an organisational citizenship behaviour (OCB). Several studies have found precursors to OCB in Nigeria, for example, Chovwen and Ogunsakin (2013) found leader-member exchange as a significant precursor to exhibiting organisational citizenship behaviour. Congruently, Pyman, Holland, Teicher, and Cooper (2010) noted that industrial relations climate enhances organisational citizenship behaviour, and Onyishi (2010) found contingent employment to be associated with organisational citizenship behaviour.

However, the global competition and ranking tasks faced by contemporary higher institutions have motivated Ashmos and Duchon (2000) to note that employees must recognise nourishment at work in other to help their organisations move forward and attain efficiency. Nourishment at work is mutually interpenetrating with workplace spirituality, which Ashmos and Duchon (2000, p. 134) asserted that it will help "employees experience a sense of purpose and meaning in their work". In this way, the implementation of spirituality in the working environment should start at the individual level (Krishnakumar \& Neck, 2002). It is obvious according to Khatri and Gupta (2016) that spirituality is innate in human beings. Furthermore, it is not only an individual quest for pursuing meaning and purpose in life but also a need to interrelate with other people in this pursuit. To this end, this paper tends to fill the glaring gap inherent in the organisational behaviour literature within the Nigerian context. Furthermore, it anticipates improving the scant literature on the subject matter within the Nigerian context. For the aim of this study is to investigate the dimensions of workplace spirituality (inner life, meaningful work, and conditions for community) and organisational citizenship behaviour in the Nigerian academic environment so as to have a cross-cultural generalisation as noted by Podsakoff, MacKenzie, Paine and Bachrach (2000), and to look at which of the three independent variables exerts more influence on the dependent variable.

\section{LITERATURE REVIEW}

\subsection{Organisational Citizenship Behaviour (OCB)}

Employees functioning outside the rulebook to achieve organisational effectiveness and efficiency are said to be exhibiting an organisational citizenship behaviour. That was why Cetin, Gürbüz and Sert (2015, p. 281) in their metaanalysis of the relationship between organisational commitment and OCB stressed that "employee behaviours that are outside formal job requirements but help make the workplace better and thus contribute to unit functioning are collectively called organisational citizenship behaviours (OCBs)". Though OCB was first defined as "individual behaviour that is discretionary, not directly or explicitly recognised by the formal reward system, and that in the aggregate promotes the effective functioning of the organisation" (Organ, 1988, p. 4). The definition of OCB has been improved by Organ (1997, p. 95) to mean the "performance that supports the social and psychological environment in which task performance takes place". The alteration in the definition according to Podsakoff, Whiting, Podsakoff \& Blume 
(2009, p. 122), is that it "avoids some of the difficulty with viewing OCBs as discretionary behaviour for which an individual might not receive formal rewards".

Many scholars have conceptualised the organisational citizenship behaviour according to their views and perspectives. But the most prevalent one is that advanced by Organ (1988). At the beginning, he offered an OCB model which consisted of five items, namely: altruism, conscientiousness, courtesy, civic virtue, and sportsmanship. Altruism is a voluntary action that helps another person with a work problem, while courtesy includes all of those farsighted signals that help someone else prevent a problem (Podsakoff et al., 2000). According to Organ (1988), sportsmanship is explained as an enthusiasm on the part of workers to endure less than ideal situations without murmuring and bringing up complications. He noted further that civic virtue is a behaviour that signposts employees' vigorous concern in the life of their organisation, and conscientiousness was referred to as compliance behavior, which indicated that employees agree and obey the rulebooks, procedures, and processes of the organisation. For the purpose of this study, Organ's (1988) classifications of OCBs were adopted.

\subsection{Conceptualisation of Inner Life, Meaningful Work, and Conditions for Community}

For the purpose of this study, dimensions of workplace spirituality (inner life, meaningful work and conditions for community) as proposed by Ashmos and Duchon (2000) were used to predict organisational citizenship behaviour. Ashmos and Duchon (2000, p. 136) in their work opined that "inner life, for many, is about coming to understand one's own divine power and how to use that divine power to live a more satisfying and more full outer life". Correspondingly, they noted that meaningful work is concerned with "the connection between the soul and the work", and, lastly, that conditions for community are concerned with the emotion of being part of a group and "... people want to feel connected to work that is important, and they want to feel connected to each other at work" (p. 137).

\subsection{Inner Life}

In the view of Guillory (2000) as cited in Gupta, Kumar and Singh (2014), he opined that inner life as a dimension of spirituality is the field of inner consciousness where people express themselves as they labor with a sense of agreement, interconnectedness, and unanimity. Inner life can be characterised as the inclination that people have about their identity, that is, what they are doing, and what commitments they make (Vaill, 1998). Ashmos and Duchon (2000) noticed that when a worker has the chance to express his/her inward life, this could convey advantageous results to the workgroup and the organisation. From a hypothetical point of view, the connection between inner life and organisational citizenship behaviour can be upheld by the self-idea theory (Shamir, 1991), which recommends that an occupation has a tendency to end up an inspiration for the employee when there is a harmoniousness between the worker's inner life and the work itself. In particular, Shamir (1991) expressed that when this match existed, employees would be more joined to the organisation; therefore, the connection that 
workers create toward their work environment is, thus, harmonious with the mental possession theory. Consequently, employees who see a solid association between their inner life and their working environment are conceivably more prone to perform OCB (Charoensukmongkol, Daniel, \& Chatelain-Jardon, 2015). Based on this, we hypothesised that:

$\mathrm{H}_{1}$ : There is a significant relationship between inner life and organisational citizenship behaviour.

\subsection{Meaningful Work}

Meaningful work is a situation that inspires employees to do OCB. Primarily, OCB is energised by a positive attitude that workers cultivate towards the accomplishment of their job (Moorman \& Harland, 2002), and workers who see that their occupation is meaningful to them are expected to dedicate themselves to their work and organization (Charoensukmongkol et al., 2015). At the point when workers of an organization feel associated with their work, they will contribute more to their engagements since they have a tendency to create passionate connection to them (Van Dyne \& Pierce, 2004). This view can be reinforced by the psychological ownership theory, which advances that individuals have a tendency to join any goal they feel unequivocally associated with (Pierce, Kostova \& Dirks, 2003). Therefore, the goal, as indicated by the theory, can be an item, an individual, an assembly of people, or the whole organisation (Avey, Avolio, Crossley \& Luthans, 2009). The more individuals put resources into an association with an objective, the more grounded is the feeling of commitment that they feel to secure and advance their welfare (Weinstein \& Ryan, 2010). As needs be, employees who see their employment as important are eager to dedicate themselves to help other individuals in their work environment (Charoensukmongkol et al., 2015). In line with this, we hypothesised that:

$\mathrm{H}_{2}$ : There is a significant relationship between meaningful work and organisational citizenship behaviour.

\subsection{Conditions for Community}

According to Ashmos and Duchon (2000), conditions for community presupposes when employees working in an organisation perceive a strong accord amongst workmates. It can be deduced from the forgoing that workers with extraordinary established conditions for community tend to exhibit prosocial activities, which is the readiness to promote, defend, or support the wellbeing of coworkers (Schwartz \& Bilsky, 1990). Consequently, these prosocial activities that workers exhibit in their place of work can encourage them to make non-compulsory assistance to help their workmates and the organisation outside their regular tasks and the rulebook (Li, Liang \& Crant, 2010). Correspondingly, Manion and Bartholomew (2004) affirmed that once a condition for community arises in a workplace, persons and groups will be branded by inclusivity, loyalty of the members, the capacity to form unanimity, a sense of pragmatism, a thoughtful nature, and a sense of security. They said further that these features will help create an atmosphere of shared trust, which encourages workers to dedicate themselves to 
support other employees and the organization at large. Based on this, we hypothesised that:

$\mathrm{H}_{3}$ : There is a significant relationship between conditions for community and organisational citizenship behaviour.

\subsection{The Influence of Inner Life, Meaningful Work, and Conditions for Community on Organizational Citizenship Behaviour}

Prior studies, for example, Charoensukmongkol et al. (2015), on the contribution of workplace spirituality to OCBs, using PLS regression analysis, the data collected from 179 graduates and undergraduates in the USA, reported a positive influence of inner life, meaningful work, and a sense of community on organisational citizenship behaviour at both individual and organisational level. Similarly, in Malaysia, Kazemipour and Mohd-Amin (2012) observed that meaningful work, a sense of community, and an alignment with organisational values have a significant positive relationship with OCB. Therefore, the conceptual model of this study is displayed in Figure 1.

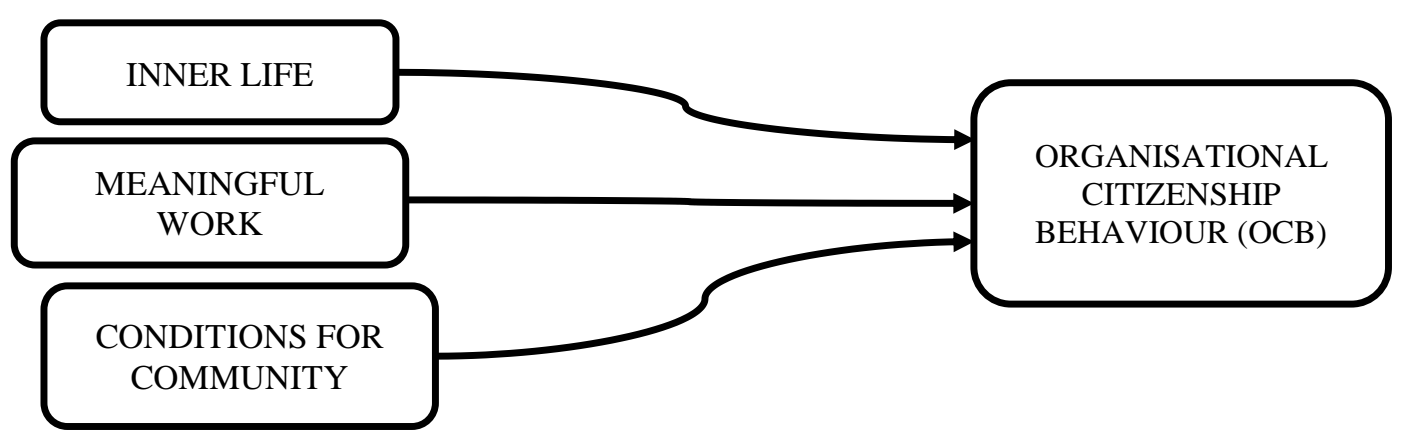

Fig. 1. Conceptual model.

\section{METHODS AND PROCEDURE}

\subsection{Sample and Sampling Procedure}

A cross-sectional descriptive survey design was adopted to test the proposed hypotheses. With the aid of convenience sampling technique, data were collected from sampled academic staff of two public universities in Southwest Nigeria. With the aid of Krejcie and Morgan's (1970) sample size determination table, three hundred and fifty (350) copies of questionnaires were administered on equal proportions to the sampled population, but three hundred and twenty-eight (328 or $93.7 \%$ ) were found usable out of the retrieved three hundred and thirty-one (331 or $94.6 \%)$.

\subsection{Measures}

The researchers adapted developed instruments that have been found to be reliable over time in other cultural contexts. The dependent variable, organisational citizenship behaviour (OCB), was measured with the adapted instrument from the 
work of Podsakoff, MacKenzie, Moorman and Fetter (1990). For this study, the instrument was found to be reliable with Cronbach alpha of 0.878 . The instrument consists of 5 dimensions with 15 items which were parcelled for data analysis. The instrument was measured on a 5-point Likert scale of 5 (strongly agree) to 1 (strongly disagree). Furthermore, the independent variables such as inner life, meaningful work, and conditions for community were measured with the adaptation of Ashmos and Duchon's (2000) workplace spirituality dimension scale. Inner life has 5 items with Cronbach alpha 0.823 , meaningful work has 8 items with Cronbach alpha 0.843 , and conditions for community has 7 items with Cronbach alpha 0.834 . The items were measured using the 5-points Likert scale.

\subsection{Data Analysis Procedures}

Inferential analysis of the collected and collated data was done with the aid of structural equation modelling (SEM) in-built in SPSS AMOS 22 package to determine the relationship between the inner life, meaningful work, conditions for community, and organisational citizenship behaviour. The choice of SEM was vital to offer suitable clarifications regarding the relationship that exists between inner life, meaningful work, conditions for community, and organisational behaviour amongst academics in Nigeria. According to Genty (2015), SEM functions as a model endorser and involves three (3) stages of analyses. He stressed that the stages were: (i) confirmatory factor analysis (CFA), (ii) measurement model, and (iii) structural model. Confirmatory factor analysis (CFA) was used to evaluate the construct validity of the items in the research instrument.

\subsection{Confirmatory Factor Analysis (CFA) of Constructs}

In this research paper, CFA was utilised to assess the items on the questionnaire if they were measuring the constructs. Thus, the analysis was determined by the theoretical relations amongst the observed and unobserved constructs (Schreiber, et al., 2006; Byrne, 2013). Hair et al. (2010) as cited in Genty (2015) affirmed that in planning for structural equation modelling (SEM), CFA should be done first. The benchmark for all standardized factor loadings is 0.60 (Awang, 2015). In this study, the factor loadings of each construct as well as the average variance extracted (AVE) to ascertain construct reliability are shown in Table 1.

Table 1. CFA of the Items and Constructs Used in the Present Study

\begin{tabular}{|c|c|r|r|r|}
\hline Constructs & Items & $\begin{array}{c}\mathbf{1}^{\text {st }} \text { Order } \\
\mathbf{C F A} \geq \mathbf{0 . 6 0}\end{array}$ & $\begin{array}{c}\mathbf{2}^{\text {nd }} \text { Order } \\
\mathbf{C F A} \geq \mathbf{0 . 5 0}\end{array}$ & $\begin{array}{c}\text { Average Variance } \\
\text { Extracted }>\mathbf{0 . 5 0}\end{array}$ \\
\hline Inner Life & & & & 0.519 \\
\hline & Inner life 2 & 0.623 & & \\
\hline & Inner life 3 & 0.767 & & \\
\hline & Inner life 4 & 0.729 & & \\
\hline & Inner life 5 & 0.753 & & \\
\hline $\begin{array}{c}\text { Meaningful } \\
\text { Work }\end{array}$ & & & & 0.467 \\
\hline & Meaningful Work 1 & 0.674 & & \\
\hline
\end{tabular}




\begin{tabular}{|c|c|c|c|c|}
\hline Constructs & Items & $\begin{array}{c}1^{\text {st }} \text { Order } \\
\text { CFA } \geq 0.60\end{array}$ & $\begin{array}{c}2^{\text {nd }} \text { Order } \\
\text { CFA } \geq 0.50\end{array}$ & $\begin{array}{c}\text { Average Variance } \\
\text { Extracted }>0.50\end{array}$ \\
\hline & Meaningful Work 2 & 0.701 & & \\
\hline & Meaningful Work 3 & 0.570 & & \\
\hline & Meaningful Work 4 & 0.724 & & \\
\hline & Meaningful Work 5 & 0.640 & & \\
\hline & Meaningful Work 6 & 0.592 & & \\
\hline & Meaningful Work 7 & 0.676 & & \\
\hline & Meaningful Work 8 & 0.530 & & \\
\hline \multirow[t]{8}{*}{$\begin{array}{l}\text { Conditions for } \\
\text { Community }\end{array}$} & & & & 0.453 \\
\hline & $\begin{array}{l}\text { Conditions for } \\
\text { community } 1\end{array}$ & 0.607 & & \\
\hline & $\begin{array}{l}\text { Conditions for } \\
\text { community } 2\end{array}$ & 0.614 & & \\
\hline & $\begin{array}{l}\text { Conditions for } \\
\text { community } 3\end{array}$ & 0.687 & & \\
\hline & $\begin{array}{l}\text { Conditions for } \\
\text { community } 4\end{array}$ & 0.652 & & \\
\hline & $\begin{array}{l}\text { Conditions for } \\
\text { community } 5 \\
\end{array}$ & 0.537 & & \\
\hline & $\begin{array}{l}\text { Conditions for } \\
\text { community } 6 \\
\end{array}$ & 0.741 & & \\
\hline & $\begin{array}{l}\text { Conditions for } \\
\text { community } 7\end{array}$ & 0.725 & & \\
\hline \multirow[t]{20}{*}{ OCB } & & & & 0.548 \\
\hline & Altruism & & 0.735 & \\
\hline & ALT 1 & 0.434 & & \\
\hline & ALT 2 & 0.707 & & \\
\hline & ALT 3 & 0.771 & & \\
\hline & Courtesy & & 0.805 & \\
\hline & $\mathrm{CO} 1$ & 0.655 & & \\
\hline & $\mathrm{CO} 2$ & 0.933 & & \\
\hline & $\mathrm{CO} 3$ & 0.618 & & \\
\hline & Civic Virtue & & 0.676 & \\
\hline & & & & \\
\hline & & & & \\
\hline & Sportsmanship & & 0.560 & \\
\hline & & 0.713 & & \\
\hline & & 0.833 & & \\
\hline & & 0.769 & & \\
\hline & Conscientiousness & & 0.552 & \\
\hline & & 0.801 & & \\
\hline & & 0.750 & & \\
\hline & & 0.862 & & \\
\hline
\end{tabular}




\subsection{Measurement Model}

Measurement model has been affirmed to be the second stage in structural equation modelling (Genty, 2015; Awang, 2015). In determining a model fit in SEM, Hu and Bentler (1999), Hooper, Coughlan and Mullen (2008), Hair et al. (2010), and Awang (2015) noted that 3-4 fit indices are needed to institute a proper model fit and suggested fit indices to comprise of: relative chi-square $(>5.0)$, RMSEA $(\geq 0.8)$, and two or more from GFI ( $\geq .90)$, AGFI ( $\geq .90)$, CFI $(\geq .90)$, NFI $(\geq .90)$, and TLI ( $\geq .90)$. Therefore, the outcomes of the goodness-of-fit indices in the measurement model after series of modifications were illustrated in Table 2.

Table 2. Goodness-of-Fit Indices

\begin{tabular}{|l|r|r|r|r|r|r|}
\hline $\begin{array}{c}\text { Goodness of } \\
\text { fit Index }\end{array}$ & CMIN $\left(\boldsymbol{X}^{2}\right)$ & $\left(\boldsymbol{X}^{2} / \boldsymbol{d} \boldsymbol{f}\right)$ & CFI & \multicolumn{1}{c|}{ IFI } & TLI & RMSEA \\
\hline VALUE & $\begin{array}{r}467.742 \\
(p=0.000)\end{array}$ & 1.909 & 0.930 & 0.930 & 0.921 & 0.053 \\
\hline
\end{tabular}

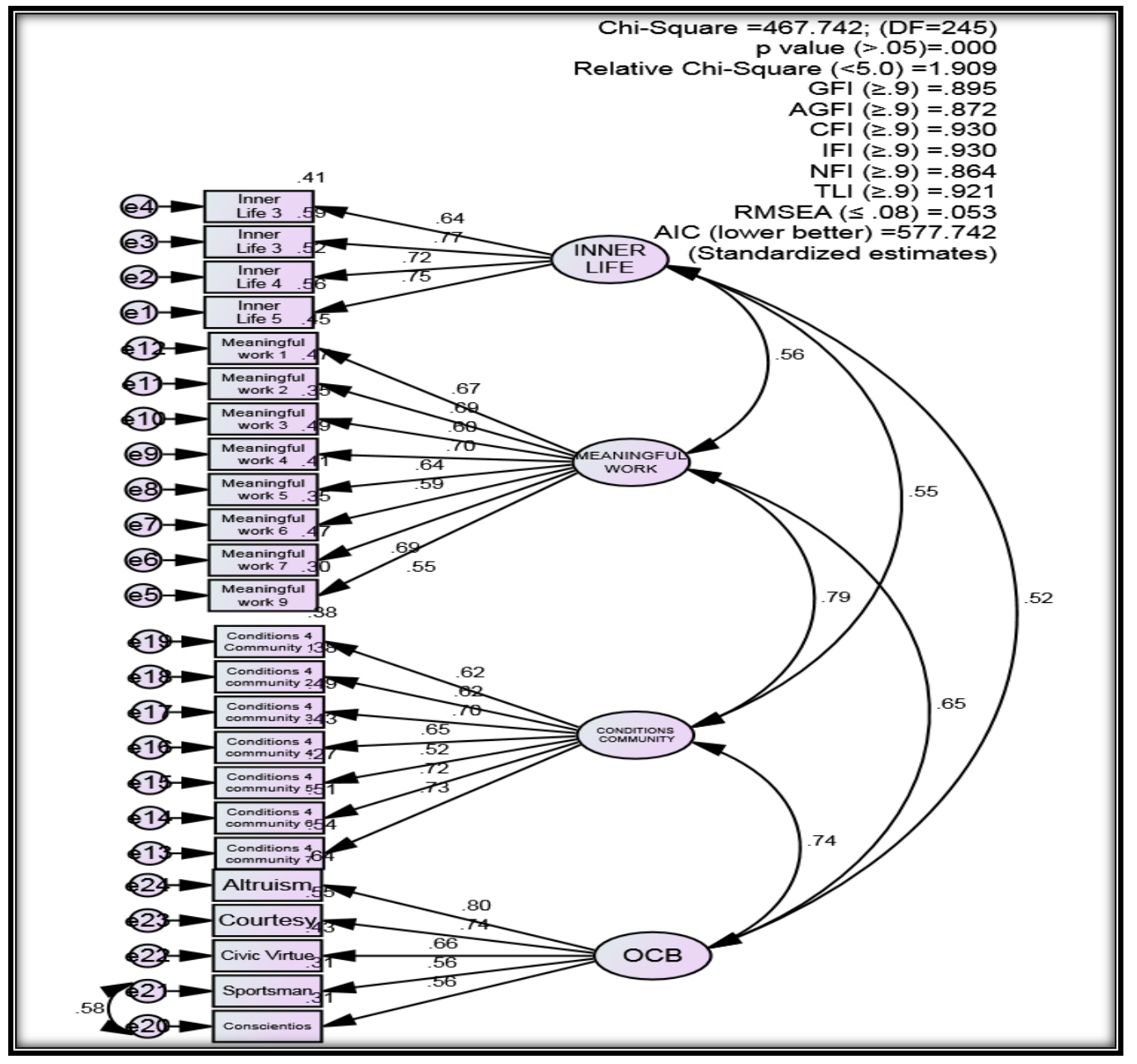

Fig. 2. Measurement model used in this study. 


\subsection{Structural Model}

As evident in the model fit indices revealed in Fig. 2, this study infers that the hypothesised 3 -factor measurement model is properly fixed to the sample data. As indicated by the CFI value of 0.930 , IFI value of 0.939 , TLI value of 0.921 , and RMSEA value of 0.053, this is in line with the satisfactory threshold (Byrne, 2013). The fit indices confirm the theoretical underpinning of the four latent variables (characterized by circles in Fig. 2) and their equivalent manifest variables (signified by boxes in Fig. 2), and the level of significance was $p<0.05$. Fit indicators of a specific path are signposted by the standard regression estimate $(\beta)$ to ascertain the influence of one construct over the other. This empirical model validates the theoretical propositions concerning the relationship that exists among inner life, meaningful work, and conditions for community, and organisational citizenship behaviour. The structural model clarifying the significance and strength of the relationship among inner life, meaningful work, conditions for community, and organisational citizenship behaviour is displayed in Fig. 3.

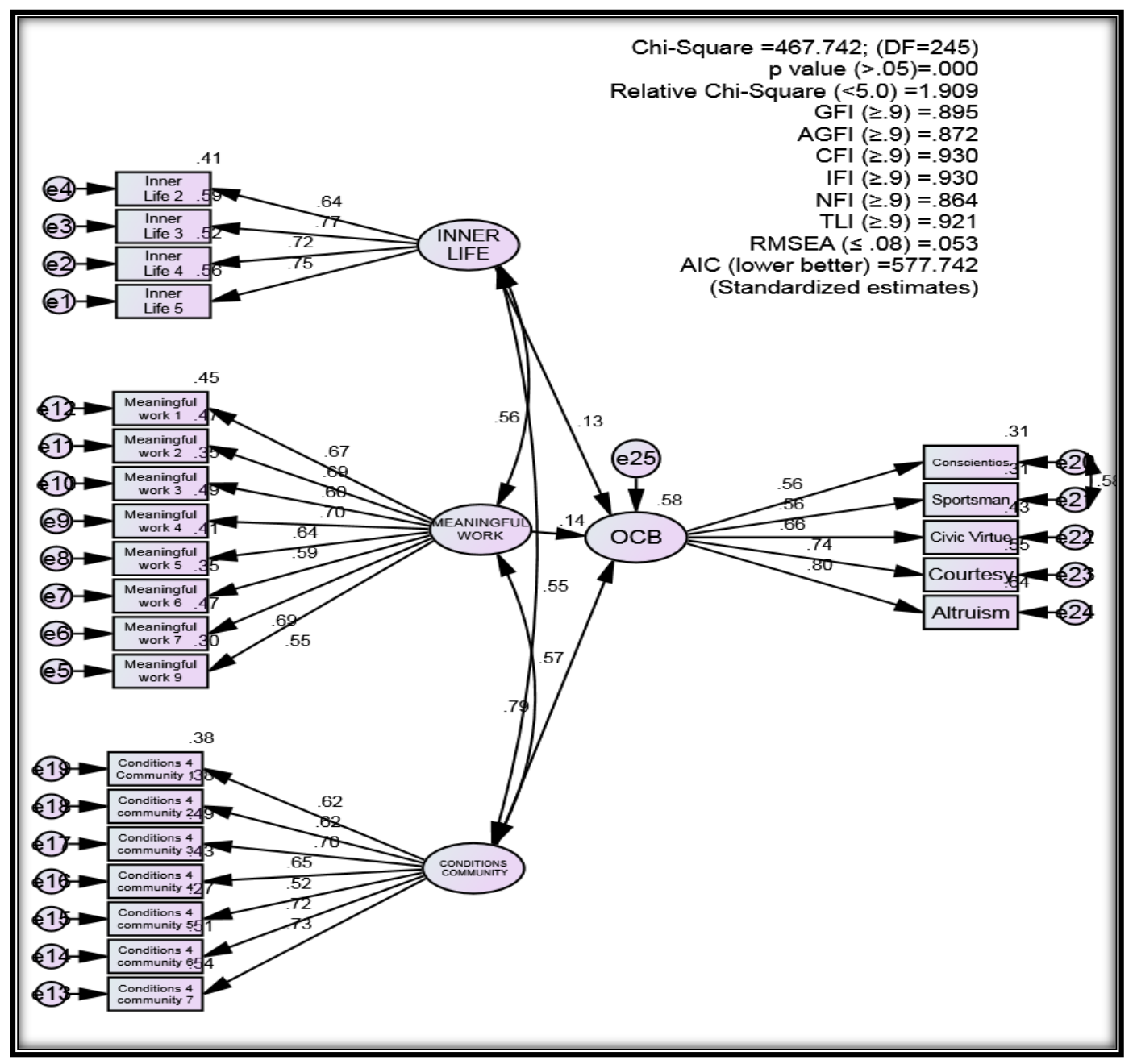

Fig. 3. Structural model of inner life, meaningful work, conditions for community, and organisational citizenship behaviour. 


\section{RESULTS AND DISCUSSION}

In the structural model presented in Fig. 3, the specific path influences were analysed based on the relationship between the constructs. Therefore, Table 3 describes the relationship between the variables in the study as stated in the research hypotheses. The structural model revealed that inner life $(\beta=0.129, \mathrm{CR}=1.824$, $p=0.067)$, meaningful work $(\beta=0.135, \mathrm{CR}=1.287, p=0.198)$, and conditions for community $(\beta=0.567, \mathrm{CR}=4.653, p=0.000)$ were predictors of organisational citizenship behaviour. The impact of inner life, meaningful work, and conditions for community on organisational citizenship behaviour was estimated at $58 \%$ in this study.

Among the independent variables, conditions for community as perceived by Nigerian university academics was the most predictive factor with $\beta=0.567$, $\mathrm{CR}=4.653$, and $p=0.000$. However, the relationship between meaningful work and organisational citizenship behaviour was insignificant $(\beta=0.135, \mathrm{CR}=1.287$, $p=0.198)$; similarly, it was established in this study that also the relationship between inner life and organisational citizenship behaviour was insignificant $(\beta=0.129, \mathrm{CR}=1.824, p=0.067)$.

Table 3. Unstandardized (B) and Standardized Regression ( $\beta$ ) Weight in the Hypothesized Path Model

\begin{tabular}{|l|r|r|r|r|r|}
\hline \multicolumn{1}{|c|}{ Hypothesized Relationship } & \multicolumn{1}{c|}{ B } & \multicolumn{1}{c|}{ S.E } & \multicolumn{1}{c|}{$\boldsymbol{\beta}$} & \multicolumn{1}{c|}{ CR } & \multicolumn{1}{c|}{ P } \\
\hline OCB $\leftarrow$ INNER_LIFE & 0.330 & 0.180 & 0.129 & 0.834 & 0.067 \\
\hline OCB $\leftarrow$ CONDITIONS_COMMUNITY & 1.287 & 0.277 & 0.567 & 0.653 & $* * *$ \\
\hline OCB $\leftarrow$ MEANINGFUL WORK & 0.305 & 0.237 & 0.135 & 0.287 & 0.198 \\
\hline
\end{tabular}

$\mathrm{H}_{1}$ : There is a significant relationship between inner life and organisational citizenship behaviour. In Fig. 3, the model shows that there is no significant relationship between inner life and organisational citizenship behaviour $(\beta=0.129$, $\mathrm{CR}=1.824, p=0.067$ ); consequently, $\mathrm{H}_{1}$ is rejected which stated that a significant relationship does exist between inner life and organisational citizenship behaviour amongst academics in Nigerian universities. The outcome of this study is contradictory to the work of Charoensukmongkol et al. (2015), who found a relationship between inner life and organisational citizenship behaviour. This indicates that in Nigeria, academics' inner life does not guarantee an organisational citizenship behaviour. Consequently, the engagement of academics in organizational citizenship behaviour is not based on their inclination to be identified with what they are doing, rather the exhibition of prosocial work behaviour could be due to their predisposition to organisational innovation (Apsalone \& Flores, 2018). 
$\mathrm{H}_{2}$ : There is a significant relationship between conditions for community and organisational citizenship behaviour.

In line with the outcome in Fig. 3, the result of the structural model shows that a significant relationship exists between conditions for community and organisational citizenship behaviour $(\beta=0.567, \mathrm{CR}=0.653, p=0.000)$. Therefore, $\mathrm{H}_{2}$ was accepted. The outcome of this study agrees with earlier studies of Charoensukmongkol et al. (2015) and Kazemipour and Mohd-Amin (2012). The result shows that employees with an established condition for community will engage in prosocial activities that will be beneficial to their colleagues and the organisation at large (Schwartz \& Bilsky, 1990).

$\mathrm{H}_{3}$ : There is a significant relationship between meaningful work and organisational citizenship behaviour.

It is evident in the path analysis of Fig. 3 that an insignificant relationship exists between meaningful work and organisational citizenship behaviour $(\beta=0.135$, $\mathrm{CR}=0.287, p=0.198$ ). Therefore, $\mathrm{H}_{3}$ was rejected. The outcome of this study contradicts the work of Charoensukmongkol et al. (2015). This result has brought to the fore that Nigerian academics have perceived their jobs to be meaningful, and, perhaps, the mutual beneficial creeds of organisational citizenship behaviour and psychological contract are not well communicated to the academics by the management of higher institutions (Azeez, Jayeoba \& Adeoye, 2016).

\section{CONCLUSION}

The influence of inner life, conditions for community, and meaningful work on organisational citizenship behaviour was examined. It was concluded that inner life, conditions for community and meaningful work were good predictors of organisational citizenship behaviour among the academics in Nigeria because $\mathrm{R}^{2}=0.58$ ). However, inner life had a positive statistical insignificant relationship with organisational citizenship behaviour. In contrast, the findings discovered that conditions for community had a strong positive and statistically significant relationship with organisational citizenship behaviour. Lastly, an insignificant relationship between meaningful work and organisational citizenship behaviour was established. Therefore, to improve organisational citizenship behaviour among academics, it is recommended that universities' management should interact with their staff members on a regular basis and communicate the benefits of organisational citizenship behaviour through an effective condition for community such as aiding of staff personal growth and their fair evaluation at work.

\section{REFERENCES}

Ahmadi, S., Nami, Y., \& Barvarz, R. (2014). The Relationship between Spirituality in the Workplace and Organizational Citizenship Behavior. Procedia-Social and Behavioral Sciences, 114, 262-264. https://doi.org/10.1016/j.sbspro.2013.12.695

Ashmos, D. P., \& Duchon, D. (2000). Spirituality at Work: A Conceptualization and Measure. Journal of Management Inquiry, 9(2), 134-145. https://doi.org/10.1177/105649260092008

Apsalone, M., \& Flores, R. M. (2018). Ethical Behaviour and Organizational Innovation: Analysis of Small and Medium-sized Enterprises in Latvia. Economics and Business, 32(1), 74-88. https://doi.org/10.2478/eb-2018-0006 
Avey, J. B., Avolio, B. J., Crossley, C. D., \& Luthans, F. (2009). Psychological Ownership: Theoretical Extensions, Measurement and Relation to Work Outcomes. Journal of Organizational Behavior, 30(2), 173-191. https://doi.org/10.1002/job.583

Awang, Z. (2015). SEM Made Simple: A Gentle Approach to Learning Structural Equation Modeling. Selangor: MPWS Rich Publications.

Azeez, R.O., Jayeoba, F. I. \& Adeoye, A.O. (2016). Job Satisfaction, Turnover Intention and Organizational Commitment. BVIMSR Journal of Management Research, 8(2), 104-112.

Byrne, B. M. (2013). Structural Equation Modelling with AMOS: Basic Concepts, Applications, and Programming. Routledge.

Cetin, S., Gürbüz, S., \& Sert, M. (2015). A Meta-Analysis of the Relationship between Organizational Commitment and Organizational Citizenship Behavior: Test of Potential Moderator Variables. Employee Responsibilities and Rights Journal, 27(4), 281-303. https://doi.org/10.1007/s10672-015-9266-5

Charoensukmongkol, P., Daniel, J. L., \& Chatelain-Jardon, R. (2015). The Contribution of Workplace Spirituality on Organizational Citizenship Behavior. Advances in Business Research, 6(1), 32-45.

Chovwen, C., \& Ogunsakin, A. (2013). Determinants of Organizational Citizenship Behaviour among Employees of Public and Private Organizations. African Research Review, 7(2), 161-174.

Genty, K. I. (2015) Relationship between Demographic Factors, and Entrepreneurial Training on Entrepreneurs' Success in Nigeria. UPM-SAGE publications, 64-91.

Gupta, M., Kumar, V., \& Singh, M. (2014). Creating Satisfied Employees through Workplace Spirituality: A Study of the Private Insurance Sector in Punjab (India). Journal of Business Ethics, 122(1), 79-88. https://doi.org/10.1007/s10551-013-1756-5

Hair, J. F., Black, W. C., Babin, B. J., Anderson, R. E., \& Tatham, R. L. (2010). Multivariate Data Analysis (7th Eds.). NY: Pearson.

Hooper, D., Coughlan, J., Mullen, M. (2008) Structural Equation Modelling: Guidelines for Determining Model Fit. Electronic Journal of Business Research Methods, 6(1), 53-60.

Hu, L. T., \& Bentler, P. M. (1999). Cutoff Criteria for Fit Indexes in Covariance Structure Analysis: Conventional Criteria Versus New Alternatives. Structural Equation Modeling: a Multidisciplinary Journal, 6(1), 1-55. https://doi.org/10.1080/10705519909540118

Kazemipour, F., \& Mohd Amin, S. (2012). The Impact of Workplace Spirituality Dimensions on Organisational Citizenship Behaviour among Nurses with the Mediating Effect of Affective Organisational Commitment. Journal of Nursing Management, 20(8), 1039-1048. http://dx.doi.org/10.1111/jonm.12025

Khatri, P., \& Gupta, P. (2016). A Study of Relationship of Perceived Organizational Politics and Spirituality at Workplace in IT and ITES Organizations. Global Journal of Enterprise Information System, 8(2), 1-8.

Krishnakumar, S., \& Neck, C. P. (2002). The "What", "Why" and "How" of Spirituality in the Workplace. Journal of Managerial Psychology, 17(3), 153-164. https://doi.org/10.1108/02683940210423060

Li, N., Liang, J. \& Crant, J. M. (2010). The Role of Proactive Personality in Job Satisfaction and Organizational Citizenship Behavior: A Relational Perspective. Journal of Applied Psychology, 95(2), 395-404. http://dx.doi.org/10.1037/a0018079

Manion, J., \& Bartholomew, K. (2004). Community in the Workplace: a Proven Retention Strategy. Journal of Nursing Administration, 34(1), 46-53.

Moorman, R. H., \& Harland, L. K. (2002). Temporary Employees as Good Citizens: Factors Influencing their OCB Performance. Journal of Business and Psychology, 17(2), 171-187. https://doi.org/10.1023/A:1019629330766

Krejcie, R. V., \& Morgan, D. W. (1970). Table for Determining Sample Size From a Given Population. $\begin{array}{llll}\text { Educational and } & \text { Measurement, } & 30(3), & 607-610 .\end{array}$ https://doi.org/10.1177/001316447003000308

Onyishi, I. E. (2010). The Impact of Contingent Employment on Organizational Citizenship Behaviour. Ife Psychologia, 18(2), 303-323.

Organ, D. W. (1988). Organizational Citizenship Behavior: The Good Soldier Syndrome. Washington DC: Lexington Books.

Organ, D. W. (1997). Organizational Citizenship Behavior: it's Construct Clean-Up Time. Human Performance, 10(2), 85-97. https://doi.org/10.1207/s15327043hup1002_2

Pierce, J. L., Kostova, T., \& Dirks, K. T. (2003). The State of Psychological Ownership: Integrating and Extending a Century of Research. Review of General Psychology, 7(1), 84-107. http://dx.doi.org/10.1037/1089-2680.7.1.84

Podsakoff, N. P., Whiting, S. W., Podsakoff, P. M., \& Blume, B. D. (2009). Individual-and OrganizationalLevel Consequences of Organizational Citizenship Behaviors: a Meta-Analysis, Journal of Applied Psychology, 94(1), 122-141. http://dx.doi.org/10.1037/a0013079

Podsakoff, P. M., MacKenzie, S. B., Moorman, R. H., \& Fetter, R. (1990). Transformational Leader Behaviors and their Effects on Followers' Trust in Leader, Satisfaction, and Organizational Citizenship Behaviors. The Leadership Quarterly, 1(2), 107-142. https://doi.org/10.1016/1048-9843(90)90009-7 
Podsakoff, P. M., MacKenzie, S. B., Paine, J. B., \& Bachrach, D. G. (2000). Organizational Citizenship Behaviors: a Critical Review of the Theoretical and Empirical Literature and Suggestions for Future Research. Journal of Management, 26(3), 513-563. https://doi.org/10.1016/S0149-2063(00)00047-7

Pyman, A., Holland, P., Teicher, J., \& Cooper, B. K. (2010). Industrial Relations Climate, Employee Voice and Managerial Attitudes to Unions: an Australian Study. British Journal of Industrial Relations, 48(2), 460480. https://doi.org/10.1111/j.1467-8543.2009.00772.x

Schreiber, J. B., Nora, A., Stage, F. K., Barlow, E. A., \& King, J. (2006). Reporting Structural Equation Modeling and Confirmatory Factor Analysis Results: a Review. The Journal of Educational Research, 99(6), 323-338. https://doi.org/10.3200/JOER.99.6.323-338.

Schwartz, S. H., \& Bilsky, W. (1990). Toward a Theory of the Universal Content and Structure of Values: Extensions and Cross-Cultural Replications. Journal of Personality and Social Psychology, 58(5), 878891.

Shamir, B. (1991). Meaning, Self and Motivation in Organizations. Organization Studies, 12(3), 405-424. https://doi.org/10.1177/017084069101200304

Starineca, O. (2016). Human Resource Selection Approaches and Socially Responsible Strategy. Economics and Business, 28(1), 106-114.

Suleiman, E. S., Ismail, W. K. W., Nor, K. M., \& Long, C. S. (2012). Workplace Spirituality and Normative Commitment. In 2nd International Conference on Management, Langkawi Kedah, Malaysia.

Vaill, P. (1998). Spirited Leading and Learning. San Francisco, CA: Jossey-Bass Publishers.

Van Dyne, L., \& Pierce, J. L. (2004). Psychological Ownership and Feelings of Possession: Three field Studies Predicting Employee Attitudes and Organizational Citizenship Behavior. Journal of Organizational Behavior, 25(4), 439-459. http://dx.doi.org/10.1002/job.249

Weinstein, N., \& Ryan, R. M. (2010). When Helping Helps: Autonomous Motivation for Prosocial Behavior and its Influence on Well-Being for the Helper and Recipient. Journal of Personality and Social Psychology, 98(2), 222-244. http://dx.doi.org/10.1037/a0016984

\section{AUTHORS' SHORT BIOGRAPHIES}

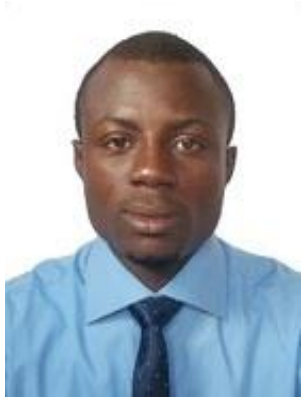

Rasheed Olawale Azeez is currently pursuing a Ph.D. degree in human resource management at the Department of Industrial Relations and Personnel Management of the Faculty of Management Sciences, Lagos State University, Ojo, Lagos State, Nigeria. He received the M.S. degree in industrial relations and personnel management from Lagos State University. His major research interests include human resource management, healthy workplace practices, employee creativity, and organizational behaviour. R. O. Azeez is a Graduate Member of the Nigerian Institute of Management (NIM).

E-mail: r.azeez2002@gmail.com

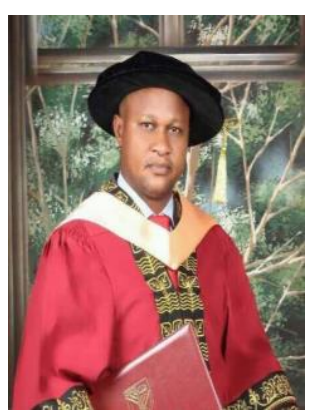

Kabiru Ishola Genty received the Ph.D. in human resource development from University Putra Malaysia in 2016. He is currently a Lecturer at the Department of Industrial Relations and Personnel Management, Lagos State University, Ojo, Nigeria. He received the B.S. (Hon) and M.S. degrees in industrial relations and human resource management in 2005 and 2009 respectively from Lagos State University. In 2012, he received the M.A. degree in labour policies and globalization from the University of Kassel and the Berlin School of Economics and Law, Germany. His research articles have been published in local and international journals. K. I. Genty has attended conferences in China, Belgium, and the USA.

E-mail: ishola.genty@lasu.edu.ng 